\title{
Towards a Theology \\ of Dignity and FreEdom: \\ Existentialism AND THE Prospects \\ FOR Reform of Protestant Witness \\ to Post-Soviet Society
}

\author{
Joshua Searle \\ Spurgeon's College, London, United Kingdom
}

\section{Introduction}

Underlying this contribution to Eastern- and Western-European theological dialogue is the conviction that existentialism offers theologians a creative wellspring of ideas and insights, which can be appropriated for the renewal of post-Soviet society. The main basis for this conviction is that many of the challenges confronting theologians in the postSoviet East today have long been addressed by leading existential thinkers from both 'East' and 'West'. These challenges include the defence of truth in a society of disinformation and propaganda; the preservation of personal ethical integrity in a society characterised by moral fragmentation and group-think; the overcoming of complacency and apathy; the protection and vindication of personal freedom and dignity in a (post-)authoritarian society; the assertion of individuality against the pressure to conform to the banality of collective sentiment; and the preservation of one's authenticity amid the prevalent inauthenticity of popular culture.

Existentialist approaches to theology, I will argue, are compelling not simply because they facilitate dialogue between the post-Christian West and the post-Soviet East, but also because they address specific social crises that affect the nations of the former USSR. This article develops this main argument through a series of distinct stages. The first part identifies key characteristics of Western and Eastern theological approaches to existentialism. The next section explores the relevance of existentialism for the context of post-Soviet Eastern European society in relation to the crises of unfreedom and dehumanisation. Finally, the article builds on the insights from the preceding parts in order to address the prospects for the renewal of post-Soviet Protestant theology in light of the insights from existentialism. 


\section{A Note on Terminology and Scope}

Before proceeding, it is necessary to make a few brief clarifications concerning the key terms employed throughout this article. Firstly, one must recognise the difficulty of speaking in general terms about such a capacious domain as "post-Soviet society." This article will focus primarily on Ukraine and, to a lesser extent, Russia. Since the ideology of Soviet Communism was imposed uniformly and disseminated in officially-endorsed Marx-Leninist textbooks that were used throughout the nations of the USSR, it is possible to make generalisations about the ideological condition of Soviet society beyond the borders of Ukraine and Russia. However, such generalisations should be made tentatively and with an awareness of their limitations.

Secondly, the history and identity of "post-Soviet Protestantism" are hugely contested. One of the difficulties with determining the identity of Protestantism in the former USSR is the fact that the evangelical movement in these nations did not spring directly from the sixteenth-century Protestant Reformation, as was the case with Protestantism in Western European and North American, where the lineage of contemporary Protestants can be traced directly back to leading figures, such as Martin Luther and John Calvin. In the case of the religious history of Russia and Ukraine, for example, the term 'reformation' could be applied more accurately to the nineteenth - rather than the sixteenth - century. ${ }^{1}$ Today, post-Soviet Protestantism includes Lutherans and Reformed churches, as well as Hussites, Mennonites, Baptists, Pentecostals and Seventh Day Adventists. ${ }^{2}$ In every country of the former USSR Protestants are and always have been a small minority. When employing terms such as "post-Soviet Protestant theology", I am referring to organised and intentional efforts to reflect critically on social and religious trends within the postSoviet space by thinkers arising from within these diverse minority communities.

Another obvious key term for this article is "existentialism." This is a huge topic that invites discussion from a variety of perspectives, which will be outlined in the next section. In order to limit the scope of my inquiry, I have selected Nikolai Berdyaev (1874-1946) as my main dialogue partner and representative of existential theology. Berdyaev has been chosen not only to provide a clearer focus for a huge topic, but also because of his deep acquaintance with both Eastern (Russian) and Western (French and German) existentialism. Berdyaev gave lucid expression in Russian to ideas that emerged out of the tradition of Western existentialism, especially Kierkegaard and Nietzsche. ${ }^{3}$ Berdyaev's writings also encompass wide-ranging themes in theology and philosophy, including a comprehensive understanding of Eastern Orthodox theology, Marxist-Leninist ideology and the underlying dynamics of Soviet society. All of these factors make Berdyaev an auspicious dialogue partner in our efforts to assess the relevance of existentialism for the theological interpretation and critique of post-Soviet society.

\footnotetext{
${ }^{1}$ For an overview of the historical and theological factors that have contributed to the contested identity of contemporary post-Soviet Protestantism, see Joshua T. Searle, "The Reformation in Russia and Ukraine and its Relevance for Today”, European Journal of Theology 26.1 (Spring,2017), 55-64.

2 Parush Parushev and Toivo Pilli, "Protestantism in Eastern Europe to the Present Day", in Alister McGrath and D. C. Marks (eds.), The Blackwell Companion to Protestantism (Oxford: Blackwell, 2004), 155-60.

${ }^{3}$ In his semi-autobiographical work, Self-Knowledge, Berdyaev acknowledges his intellectual debt to these two pioneers of existentialism. Throughout his writings, one finds copious examples of critical interaction with Nietzsche and Kierkegaard, as well as later existentialists such as Heidegger and Jaspers. See Berdyaev, Self-Knowledge: An Essay in Autobiography, trans. by K. Lampert (London: G. Bles, 1950), 93, 102, $290,306$.
} 


\section{Key Aspects of Existentialism and Existentialist Theology}

By definition, existentialism has no essence or essential characteristic. The fluidity and ubiquity of existentialism explains why the label 'existentialist' has been applied to such a wide variety of diverse, even contradictory, philosophical beliefs and worldviews, including: atheistic humanism and Marxism (J. P. Sartre); Hasidic Judaism (M. Buber); Protestant individualism (S. Kierkegaard); classical vitalism (F. Nietzsche); mystical phenomenology (M. Heidegger); neo-Kantian cosmopolitanism (K. Jaspers); liberal Christianity (R. Bultmann); and Eastern Orthodoxy (N. Berdyaev).

Part of the ambiguity arises from the notion that existentialism denotes not a system of theological doctrines, but a way of pursuing truth and elucidating profound questions of human life within a fragmented world that seems to exhibit no fixed essence. Existentialism denotes more a point of departure, rather than a destination. Existentialism is a posture or an orientation, rather than a philosophical school with a characteristic set of axioms. Existentialism denotes both a philosophical tendency and a psychological disposition or temperament. According to John Macquarrie, existentialism is "one of the basic types of thought that has appeared from time to time in the history of philosophy", rather than a defined system of thought. ${ }^{4}$ Nikolai Berdyaev claimed that the "vivifying theme" of existentialism could be "discerned throughout the whole history of thought." 5 There are, however, certain traits that mark out existentialist approaches to theology and philosophy. Existentialist philosophers, such as Martin Heidegger ${ }^{6}$ and Jean-Paul Sartre, for example, endeavoured to provide a comprehensive philosophical analysis of the metaphysics of existence. This involved a systematic endeavour to reveal the meaning of human existence through the lens of supposedly primordial, pre-critical concepts, such as "anxiety", "dread", "death", "care", "concern", "freedom", "the sublime", "the Other", "mystical intuition", and "ultimate concern."”

The basic aim of existentialist theology is to apply such existential concepts to the basic questions of life in the world and to clarify the urgent problems of concrete existence in light of biblical witness and Christian tradition. Existentialist theology thus seeks to illuminate traditional theological concepts, such as sin and grace, by interpreting these ideas in relation to primordial human instincts and dispositions, including not only anxiety, dread and death, but also courage, hope and life. According to Hue Woodson, the fundamental question of existential theology revolves around the relationship between divine and human existence. ${ }^{8}$ In the words of John Macquarrie, existentialist theology attempts to "unfold the meaning of Christian faith in terms of a phenomenology of Christian existence."

\footnotetext{
${ }^{4}$ Macquarrie, Existentialist Theology, 17.

${ }^{5}$ Berdyaev, Self-Knowledge: An Essay in Autobiography, trans. K. Lampert (London: G. Bles, 1950), 102.

${ }^{6}$ Although Heidegger is commonly regarded as an "existentialist", he famously rejected the label - as also did other supposedly leading existentialist thinkers, such as Karl Jaspers and Gabriel Marcel.

${ }^{7}$ Paul Tillich, Systematic Theology: Volume 1 (London: Nisbet, 1963), 11-14.

${ }^{8}$ According to Hue Woodson, the fundamental question of existential theology is "what kind of relationship does human existence have in relation to God's existence?" See Woodson, Existential Theology: An Introduction (Eugene, OR: Wipf and Stock, 2020), 1.

${ }^{9}$ Macquarrie, Existentialism, 271.
} 
Several leading theologians of the twentieth century, including Paul Tillich, Gabriel Marcel, Jacques Maritain, and Jean-Luc Marion, have applied existentialist insights in order to illuminate key aspects of Christian faith. The most significant, and arguably most controversial, attempt to apply existentialist insights to yield new insights into the meaning and significance of the gospel for the modern world was Rudolf Bultmann's project of demythologisation. Bultmann was driven by his conviction that existentialism was a key that opened new fruitful perspectives on theological debates concerning divine transcendence, biblical hermeneutics and the distinction between the Jesus of history and the Christ of mythology. ${ }^{10} \mathrm{He}$ believed that "the basic orientation found in existentialism lies within the structures of faith as found in the New Testament." 11 In a series of groundbreaking works in biblical studies and systematic theology, Bultmann applied the concepts of Heidegger's philosophy, such as "authenticity", "fallenness", "care" in order to expound key features of the Apostle Paul's anthropology, such as "flesh", "body", "spirit", "conscience", "sin" and "grace" in ways that Bultmann hoped would make these ideas come alive for people in the early twentieth century. ${ }^{12}$

For example, Bultmann attempts to translate Pauline language of "life in the spirit" into the existentialist language of "authentic Being-in-the-World." Living "in the spirit" involves participating in the divine nature (2 Pet 1:4), so that one's life is transfigured according to the beauty and holiness of Christ, rather than according to the banal and superficial fashions of mass society (Rom 12:2). Bultmann thus contrasted the "life of the earthly man" to the "supranatural life." ${ }^{13}$ Whereas the latter refers to a life that is set on self-directed purposes that enable the person to transcend the limits of his or her natural life, the former refers to "a life that is directed toward, and limited to, the earthly." 14 This insight corresponds to the traditional biblical teaching that the person who sets his or her mind on the things of the flesh is in a condition of $\sin$ (Rom. 8:6-11). Translated into existentialist language, such a person is described as living an inauthentic existence. Rather than living in the fullness of Being, such people arrange their lives according to popular customs, fashions and tastes. Existentialism categorises such a mode of living as a shallow ephemeral existence, devoid of freedom, mystery, depth, dignity and authenticity.

Later in this article I will return to these existentialist approaches to theology, and explore how they could be applied towards the interpretation and critique of post-Soviet society. Firstly, however, it is necessary to examine the key features of post-Soviet society in order to gain an appreciation of how existentialist ideas could be applied profitably

\footnotetext{
${ }^{10}$ Bultmann's work has been highly influential and controversial in equal measure. A huge body of critical literature, particularly in English and German, has built up around Bultmann's existentialist reading of the New Testament. For a disparaging interpretation, see Klaus Bockmuehl, The Unreal God of Modern Theology: Bultmann, Barth, and the Theology of Atheism: A Call to Recovering the Truth of God's Reality (Colorado Springs, CO: Helmers \& Howard Publishers location, 1988), 9-76. For a sympathetic reading, which emphasises the continuity between Bultmann and the mainstream evangelical tradition, see David W. Congdon, The Mission of Demythologizing Rudolf Bultmann's Dialectical Theology (Minneapolis, MN: Fortress, 2015).

${ }^{11}$ Stanley Grenz and Roger Olson, 20 $0^{\text {th }}$ Century Theology: God and World in a Transitional Age (Downers Grove, IL: InterVarsity Press, 1992), 93.

${ }^{12}$ Rudolf Bultmann, Theology of the New Testament, trans. by K. Grobel (Waco, TX: Baylor University Press, 2007).

${ }^{13}$ Bultmann, Theology of the New Testament, 236.

${ }^{14}$ Bultmann, Theology of the New Testament, 205.
} 
by theologians in both East and West to explain and resolve urgent and pressing social crises that afflict the nations of the former USSR.

\section{Existentialism and the Crises of Unfreedom and Dehumanisation in Post-Soviet Society}

At the risk of over-simplifying a wide range of complex cultural trends and political tendencies, I maintain that it is helpful to categorise the collective social pathologies that currently afflict post-Soviet society under two main headings. These are: (1) the crisis of unfreedom; (2) the crisis of dehumanisation. Although these crises have a potentially global reach, I maintain that they pertain in a particular way to the unique context of postSoviet Eastern Europe. In this section, I will briefly define what is meant by the terms, "unfreedom" and "dehumanisation", before proceeding to an assessment of how insights from existentialist theology could be applied towards the interpretation and resolution of these two interrelated crises.

\section{i. The Crisis of Unfreedom}

Despite its associations with persecution, mass murder and the gulags, the USSR continues to be remembered favourably by many people in the post-Soviet space. Many people look back fondly to the Soviet Union, which provided a measure of drab stability and predictability, even if these mixed blessings came at the cost of personal dignity and freedom. ${ }^{15}$ There remains a widespread longing for order, stability and security that many people associate with the Soviet system, which is compared favourably to the anarchy and corruption associated with the "gangster capitalism" that prevailed in many nations of the former USSR (most notably Russia and Ukraine) in the 1990s. ${ }^{16}$

Such nostalgia for the supposed glory days of Soviet Communism can be largely explained by the the failure of many post-Soviet countries to transition into functioning democracies in which civil society could flourish under the protection of the rule of law. This has meant that now, more than thirty years after the demise of the Soviet Union, post-Soviet society is still undergoing a slow process of shaking off the chains of Soviet communism. The shackles of Soviet unfreedom continue to not merely chafe at the skin of the political surface, but penetrate down into the marrow of the culture. The high hopes of the supposedly inexorable expansion of freedom and the consolidation of an open society remain largely unfulfilled. People's faith in the "politics of inevitability" 17 and in the inexorable culmination of ideological development into a liberal-democratic-capitalist equilibrium (i.e. "the end of history") ${ }^{18}$ was misplaced.

\footnotetext{
15 Timur Dadabaev, Identity and Memory in Post-Soviet Central Asia Uzbekistan's Soviet Past (London: Taylor and Francis, 2015), 104-5. Although this study is focused on Uzbekistan, its insights and findings have implications for the other nations of the former USSR.

${ }^{16}$ Chrystia Freeland, Sale of the Century: Russia's Wild Ride from Communism to Capitalism (New York: Random House, 2000).

${ }^{17}$ Snyder, Road to Unfreedom: Russia, Europe, America (London: Bodley Head, 2018), 7, 15.

${ }^{18}$ Francis Fukyuama, The End of History and the Last Man (London: Penguin, 1992).
} 
In many ways, factors have converged in post-Soviet Eastern Europe to create the kind of society that Dostoevsky wrote about in his Legend of the Grand Inquisitor. ${ }^{19}$ In this famous parable, Dostoevsky describes the tragic plight of humanity in a condition of selfimposed servitude. Human beings, observed Dostoevsky, are paralyzed by the existential tension arising from the situation of being, on the one hand, created for freedom, but, on the other, being too weak and timid to assume the risk, responsibility and vulnerability that freedom brings. ${ }^{20}$ If people were given the choice between freedom and truth on the one hand, and happiness and security, Dostoevsky maintains that they would invariably choose happiness and security.

The idea that freedom is viewed by most people as a curse, rather than as a blessing, has a long pedigree in the history of existentialism. ${ }^{21}$ Dostoevsky's Inquisitor famously rebukes Christ for restricting his ministry to a spiritual elite ("the great and the strong") and not adapting his teaching to the masses ("the weak, vicious, and rebellious"). Christ erred, according to the Inquisitor, in so far as he failed to make his teaching accessible to the weak masses of humankind, who could never aspire to live according to the high standards of the gospel of freedom. According to the Inquisitor, Christ did humanity a disservice by not acquiescing to the temptation of Satan ("that dreadful and wise spirit") to turn the stones into bread. "You refused the cause of earthly bread in the name of freedom and the bread from heaven", remarks the Inquisitor reproachfully. The Inquisitor further rebukes Christ, opining that: "Instead of taking possession of people's freedom, you increased it and burdened humankind with a spiritual kingdom of freedom, whose sufferings people were unable to endure." 22

The Parable of the Grand Inquisitor illustrates in a dramatic form one of the central insights of existentialism: namely, that freedom is seen as a curse that produces pain and suffering, rather than a blessing that brings happiness and satisfaction. The masses of people, according to Dostoevsky, have no more urgent anxiety than to find someone to whom they can surrender the freedom that has made them unhappy ever since the time of their birth. ${ }^{23}$ Therefore, most people willingly accept the compulsory organisation of their lives by religious and political authorities in order to be rid of the burden of freedom and Although Dostoevsky's parable was a work of fiction that was published several decades before the USSR even existed, it provides an existential depiction of Soviet society that is arguably much closer to the truth than all the supposedly scientific Marxist-Leninist sociological publications that were officially endorsed by the Soviet authorities between 1917 and 1991. Even in the post-Soviet era, the existential insights of the Grand Inquisitor can still be applied to illuminate the tragic plight of countries that have struggled to transition away from communist dictatorship towards

\footnotetext{
19 Достоевский, Братья Карамазовы (Москва: Бертельсманн Медиа Москау, 2014), 230-55.

${ }^{20}$ Searle and Cherenkov, Future and a Hope, 110.

${ }^{21}$ Sartre claimed that human beings are "condemned to being free" - Sartre, L'Existentialisme est un Humanisme (Paris: Nagel, 1946), 23; Berdyaev refers to freedom as a "deadly gift" that condemns the one who possesses it to a life of pain and suffering. Sее Николай Бердяев, О Назначении Человека (Москва: АСТ Хранитель, 2006), 42.

${ }^{22}$ Достоевский, Братья Карамазовы, 236-37.

${ }^{23}$ Достоевский, Братья Карамазовы, 238.
} 
liberal democracy. In the decades following the collapse of the USSR, post-Soviet society continued to be shackled by a pervasive soviet mentality that was and still is hostile to freedom. The Soviet system attempted to become a new religion for the masses, after the pattern of the Grand Inquisitor. Soviet communism became an ersatz religion, inspired by a messianic mission to build heaven on earth. The Soviet Union thus claimed to be the bearer of a saving gospel of dialectical materialism that would respond to the religious needs of the masses and save them from their misery and suffering. ${ }^{24}$ The price that had to be paid in order to gain this "salvation" was individual freedom. In the words of Dostoevsky's Inquisitor, the goal of this new religion would be to "conquer freedom with the sole object of making people happy." ${ }^{25}$ This describes, in existentialist terms, the condition of unfreedom under the Soviet system. In order to reduce the risk and suffering that freedom brings, individual creative expression in the Soviet Union had to be "subordinated to the collective judgement" and the masses had to submit to "the compulsory establishment of an earthly kingdom" "26 along the lines of a state-enforced ideology of Marxist-Leninism. In exchange for freedom, the Soviet system would provide people with bread. ${ }^{27}$ Berdyaev thus characterises Soviet Communism as "a religion of earthly bread and the social ant-heap." 28

Elsewhere I have argued that the Soviet experiment (1917-1991), from a theological perspective, should be viewed as an unmitigated disaster, not only politically, but also culturally and spiritually. ${ }^{29}$ Soviet communism was inherently hostile to the notions of "the freedom of the individual person", "the freedom of personality" and the Kantian idea of "the inherent dignity of the human person." 30 These ideals were regarded as mere "bourgeois illusions" or as ideological covers for the allegedly nefarious aspirations of the capitalist system. ${ }^{31}$ All that mattered, according to Marxist-Leninist dialectical materialism, were the material conditions that supposedly determined social life. As a Soviet officially-endorsed Handbook for Marxist-Leninist Basic Study (1974) put it: "the human personality changes with the society", of which the individual is a mere "product." 32 Furthermore, "individualism" was regarded as "the ideological justification of capitalism and the attenuation of capitalism's contradictions and defects." 33 According to Marx, human

\footnotetext{
${ }^{24}$ Бердяев, Истоки и смысл русского коммунизма (Москва: Наука, 1990), 129.

${ }^{25}$ Достоевский, Братья Карамазовы, 240.

${ }^{26}$ Бердяев, “Миросозерцание Достоевского”, 471.

${ }^{27}$ The term, "bread", is used here metaphorically, signifying the material conditions necessary to sustain basic physical existence.

${ }^{28}$ Бердяев, “Миросозерцание Достоевского”, 470.

${ }^{29}$ Joshua T. Searle and Mykhailo N. Cherenkov, A Future and a Hope: Mission, Theological Education, and the Transformation of Post-Soviet Society (Eugene, OR: Wipf and Stock, 2014), 23-32.

${ }^{30}$ Mark D. White, "Dignity", in The Oxford Handbook of Ethics and Economics (Oxford: Oxford University Press, 2019), 85.

${ }^{31}$ Dialektischer und historischer Materialismus: Lehrbuch für das marxistisch-leninistische Grundlagenstudium (Berlin: Dietz, 1976), 647.

${ }^{32}$ Dialektischer und historischer Materialismus, 639.

${ }^{33}$ Dialektischer und historischer Materialismus, 645.
} 
nature itself is little more than an "ensemble of social relations." 34 Marx maintained that human society is not the sum of the existing individuals who constitute it, but consists in the totality of the communal relations in which individuals stand in relation to one another. ${ }^{35}$

In contrast to the Marxist conviction that the individual personality is ontologically subordinate to the collective identity of society, Berdyaev, arguing from an existentialist perspective, maintained that, "the most significant aspect of human spirituality arises neither from social influences nor from the social milieu, but comes from within, rather than from without." 36 According to Berdyaev, therefore, Marx "finally denies the intrinsic dignity of human beings by reducing them to a function of the material social process." ${ }^{37}$ In total contrast to existentialism's unconditional affirmation of the freedom and dignity of the individual, communism asserted the "absolute supremacy of society over the human being" and the "exaltation of social, economic, and technical values over all human life." ${ }^{38}$ Under this collectivist ideology, conformity to the state-sanctioned social norms and adaptation to dominant social trends was deemed to be virtuous. Soviet citizens were expected to adopt the customs, values and behaviour patterns of the "new Soviet man" or homo sovieticus. ${ }^{39}$ The USSR was equipped with a formidable institutional apparatus to force its citizens to conform to the ideals of homo sovieticus. Such patterns of enforced socialisation contributed to "a general sense of degradation of the state, society, culture, morality, and the individual person." ${ }^{40}$ Such degradation, in turn, contributed to a loss of dignity and a general sense of dehumanisation among the people of the former USSR.

\section{ii. The Crisis of Dehumanisation}

The crisis of unfreedom is closely related to the crisis of dehumanisation, not only in content, but also in origin. The recent history of many nations in Eastern Europe in the area described by Timothy Snyder as the "Bloodlands" is an extended narrative of totalitarian government, abuse of power, corruption, war, random killings and mass starvation. ${ }^{41}$ This tragic narrative caused a scarring of the general consciousness of the people who suffered under the dehumanising ideologies of Soviet Communism and German Nazism. The Soviet mentality has led to a widespread and enduring brutalisation of entire populations. The scars of this dehumanising ideology continue to be visible today, more than

\footnotetext{
34 Karl Marx, Thesen über Feuerbach, cited in Ernst Bloch, Das Prinzip Hoffnung: Gesamtausgabe (Frankfurt: Suhrkamp, 1959), 304.

${ }^{35}$ Marx, Grundrisse der Kritik der politischen Ökonomie (Berlin: Dietz, 1974), 176.

36 Бердяев, Экзистенииальная диалектика божественного и человеческого (Москва: Астрель, 2010), 467.

${ }^{37}$ Бердяев, Смысл творчества: опьт оправдания человека (Москва: АСТ: Астрель, 2011), 96.

38 Бердяев Генеральная тиния советской философии и воинствуюший атеизм (Paris: YMCA, 1932), 27-8.

${ }^{39}$ Aleksander Zinoviev, Homo Sovieticus, trans. by Charles Janson (New York: Atlantic, 1986).

40 Михаил Черенков, Владислав Бачинин, Протестантская этика и дух остмодернизма (Куіv: Издательство Книгоноша, 2015), 91.

${ }^{41}$ Snyder, Bloodlands: Europe between Hitler and Stalin (London: Vintage, 2011).
} 
thirty years after the formal demise of the USSR. ${ }^{42}$ Post-Soviet society, according to leading Protestant thinkers in Ukraine, is characterised by a "new age of barbarism." 43 This spirit of barbarism is one of the unhappy legacies of the defunct Soviet system, which has been described as a "total spiritual catastrophe" for the nations of the post-Soviet Eastern Europe and Central Asia. ${ }^{44}$

Unfortunately, Marxist-Leninism as a dehumanising worldview and ideology survived well beyond the demise of the USSR as a political entity. The Soviet system produced a unique creature, known as homo sovieticus, which became the dominant variant of homo sapiens in the USSR. To be a citizen of the Soviet Union was to be a unit in a nameless, depersonalised collective. One was expected not to exert one's creative powers towards self-directed purposes of spiritual or intellectual fulfilment, but to subordinate one's individuality to a depersonalised "system". Soviet citizens were expected to live according to the "moral code of the Communist Party", which meant, essentially, working hard and helping to build a socialist paradise through the diligent application of Marxist-Leninist dogma to every aspect of personal and social life. ${ }^{45}$ The term, homo sovieticus, thus refers to an anthropological prototype that corresponded to the notion of what should constitute an ideal citizen under the Soviet system. Homo sovieticus was expected to be disciplined, technically competent, and steadfast in his conviction concerning the absolute truth of dialectical materialism.

The Soviet system trapped the human spirit within an iron cage of bureaucracy. The bureaucratisation of every sphere of life resulted in the loss of the sense of dignity among the Soviet population. This loss of dignity was a feature of intellectual life under Soviet communism. According to Berdyaev, academic life under communism was characterised by "endless repetition", "monotony", and "the constant need to lie, as a principle." 46 Rather than allow the emergence of talented individuals to express their artistic creativity and intellectual flair, the Soviet system required that intellectual work should be done by " a nameless collective, which developed the 'general line' under the direction of the governing authorities." ${ }^{47}$ Within an atmosphere of falsehood and conformity that was hostile to all forms of freedom, it was "impossible for any genius or talent to appear." 48

\footnotetext{
${ }^{42}$ Apart from the Soviet brutalist architecture of the buildings that continue to dominate the urban landscapes of nearly every city in the former USSR, one of the most visible signs of the enduring legacy of the Soviet Union in "post-Soviet" society is the abundance of street names and public locations that bear Sovietthemed names, such as "Karl Marx Avenue" and "Vladimir Lenin Street", etc. In 2012 a study revealed that in Ukraine such Soviet names outnumbered by twenty times street names that were connected with Ukrainian independence.

43 Черенков, Бачинин, Протестантская этика, 23-25.

44 Черенков, Бачинин, Протестантская этика.

${ }^{45}$ The Code was reinforced by the moral concept of kul'turnost, which helped to link moral validity with the concepts of modernity and civilisation in the Soviet conscience. Since this notion of kul'turnost transcended politics, it became crucial in the moral formation of Soviet citizens in the mould of homo sovieticus. See Vadim. Volkov, "The concept of kulturnost': Notes on the Stalinist civilizing process", in Sheila Fitzpatrick (ed.), Stalinism: New Directions (London: Routledge, 2000), 210-230.

${ }^{46}$ Бердяев Генеральная линия, 5.

${ }^{47}$ Бердяев Генеральная линия, 2.

${ }^{48}$ Бердяев Генеральная линия, 5.
} 
Since Christianity, in contrast to Marx-Leninism, asserts the primacy of the qualitative over the quantitative ${ }^{49}$ and upholds the dignity of the individual over and against the integrity of the nameless collective (cf. Luke 15:3-7), it is not coincidental that Soviet Communism was inherently antagonistic and hostile to Christianity. Moreover, Soviet ideology posited the "radical rejection of all transcendence and other-worldliness." 50 According to Berdyaev, the "inward principle" of communism was "disbelief in God and rejection of the immortality and freedom of the human spirit." ${ }^{51}$ Yet the antithesis between Soviet communism and Christianity ran far deeper than the obvious "atheistic-theistic" distinction. Underlying this banal contrast was a more fundamental distinction: namely, the distinction between the doctrine of individual spiritual freedom before a transcendent God (Christianity) and the dogma of collectivist submersion of the individual to a hegemonic ideology (Communism). In this distinction lies the existential difference between Christianity (in particular, Protestant Christianity) and Soviet Communism. Christian doctrine maintains belief in the infinite value and inherent dignity of the human soul and the absolute equality before God of all human individuals. The value of an existential approach to theology lies in its emphasis on this key conviction concerning the freedom and dignity of the individual person. Existentialism thus opens up new prospects for Protestant theologians in the former communist Eastern European and Central Asian nations to assist in the prolonged efforts to release post-Soviet society from its captivity to the ruinous Soviet legacy. ${ }^{52}$

\section{Existentialism, Protestant Theology and the Restoration of Dignity and Freedom}

The demonstrations that took place throughout Ukraine in 2013/14, which led to the downfall of the corrupt oligarchic regime of Viktor Yanukovych, came to be known as the "Revolution of Dignity and Freedom." This label is significant, because it signifies that the revolution that occurred was a mass response to the two fundamental crises of post-Soviet society, which we identified above: namely, unfreedom and dehumanisation. The theological antidotes to the social pathologies of unfreedom and dehumanisation are, respectively, freedom and dignity. Since the Revolution of Dignity and Freedom in Ukraine, many commendable attempts to provide a theological interpretation of the turbulent events of 2013/14 have been made by a younger generation of gifted Russianand Ukrainian-speaking Protestant theologians, led by Mykhailo N. Cherenkov. Several

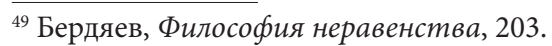

${ }^{50}$ Бердяев Генеральная тиния, 18.

${ }^{51}$ Бердяев, “Миросозерцание Достоевского”, іп Бердяев, Смысл творчества (Москва: АСТ Астрел, 2011), 468.

${ }^{52}$ Although it is hard to imagine a worldview more inherently antagonistic to Soviet collectivism than existentialism, it is one of the curious ironies of twentieth-century philosophy that some leading Western existentialist thinkers, most notably J. P. Sartre and M. M. Merleau-Ponty, at points in their career, actively supported Soviet communism. For his own part, Heidegger was also (albeit briefly) an enthusiastic supporter of the Nazi Party and made some reprehensible remarks in praise of Adolf Hitler. Such disastrous lapses in political judgement were less common among theistic existentialists, such as Berdyaev, whose absolute commitment to human freedom and dignity was the foundation of his vigorous and penetrating critique of both Nazism and Communism.
} 
promising younger scholars have produced valuable studies that apply the principles of Liberation Theology to the unique context of post-Soviet society in the aftermath of the "Revolution of Dignity and Freedom." 53 The recent work of Anatoliy Denysenko, for example, draws on Liberation Theology to provide a perceptive analysis of social problems such as poverty, corruption and injustice. Such valuable contributions have enriched our theological understanding of the meaning and significance of the gospel message of freedom for contemporary post-Soviet society. ${ }^{54}$

Despite this laudable work, however, there have been no sustained attempts to apply the insights and concepts of existential theology to explain the biblical-theological meaning of "freedom" and "dignity" for post-Soviet society. Liberation Theology serves an important purpose in so far as it raises awareness of the emancipatory effects of gospel proclamation and elevates the struggle for justice to the level of a gospel imperative. Existentialism, by contrast, is less focused on the social effects of liberation, and more on the theological elucidation of the meaning of freedom and dignity. Liberation Theology is largely dependent upon a Marxist interpretation of social justice, which emphasises the collectivist virtues of solidarity and social cohesion. This has a certain value, but it is equally necessary to preserve the uniqueness and dignity of each individual person, which is the fundamental starting point of all existentialist approaches to theology and social critique.

In order to create the conditions that would enable people to live according to the principles of freedom and dignity, some younger post-Soviet theologians advocate a wholesale embrace of the supposedly Christian - or, more specifically, Protestant - values of European civilisation. Writing about post-Soviet Ukraine, Mykhailo Cherenkov makes the bold claim that "the hope of modernization of Ukraine in a civilized Europe lies in the reception of Protestant ethics and values and a Christian worldview." 55 This remark applies to all the nations of the former Soviet Union that aspire to freedom from the baleful legacy of the USSR. Although Protestants are numerically relatively insignificant in all these nations, their social importance belies their minority status. The world-historical significance of a resolute minority has been a persistent theme in the writings of leading existentialist thinkers, especially Kierkegaard ${ }^{56}$ and Nietzsche. ${ }^{57}$ Ukrainian Baptist theologians have written at length about Protestantism in post-Soviet society in terms of a "culture of the influential minority" and argued compelling concerning the ways in which this minority can exert a leavening effect upon the wider culture. ${ }^{58}$

\footnotetext{
53 See, for example Михайло Димид, Богослов'я свободи: украӥнська версія (Львів: Видавництво Українського Католицького Університету, 2020).

${ }^{54}$ Анатолий Денисенко, Теологія визволення: ідеї, критика, перспективи (Куіv: Дух і Літера, 2019).

${ }^{55}$ Cherenkov, 'Protestantism and Protest: Socio-Theological Re-Identification of Ukraine and Ukrainian Protestantism in the Context of Maidan', in Rob van der Laarse, Mykhailo N. Cherenkov, Vitaliy V. Proshak and Tetiana Mykhalchuk (eds.), Religion, State, Society and Identity in Transition: Ukraine (Oisterwijk: Wolf Legal Publishers, 2015), 340.

${ }^{56}$ See Kierkegaard's Writings, XVIII: Without Authority, ed. by Howard V. Hong and Edna H. Hong (Princeton, NJ: Princeton University Press, 2009), 87; see also Kierkegaard, “Truth/Authority”, in Frederick Sontag (ed.), A Kierkegaard Handbook (Eugene, OR: Wipf and Stock, 2003), 143-44.

${ }^{57}$ Nietzsche, On the Genealogy of Morality, ed. By K. Ansell-Pearson (Cambridge: Cambridge University Press, 2006), 33, 166.

${ }_{58}$ М. Н. Черенков, Культура влиятельного меньшинства (Симферополь: Ассоциация Духовное Возрождение, 2010), 200.
} 
Given the attention paid by Protestant theologians to the significance of their minority status, it is surprising that the general attitude towards existentialist theology even among this emerging generation continues to be characterised by ambivalence and suspicion. This is the case even among Protestant theologians who recognise that one of the main social challenges confronting the Protestant church within this context is the fact that, "Many evangelical believers do not even understand why there is a need for freedom in their country", because they continue to be burdened by their "totalitarian past." 59 Even among more pro-Western and European-orientated Protestant thinkers such as Cherenkov, there remains a reluctance to engage in a sustained way with existentialist approaches to philosophy and theology. ${ }^{60} \mathrm{I}$ believe that this suspicion is misplaced, since it represents a lost opportunity to assert the values of freedom and dignity as gospel imperatives and to infuse these ideas with a positive Christian content. Therefore, without intending to be too prescriptive, I would like to indicate some ways in which existentialist thinking could be applied by post-Soviet Protestant theologians towards the deconstruction of homo sovieticus in order to assist the efforts of post-Soviet society to move forward from the toxic legacy of Soviet communism.

\section{Deconstructing das Man and homo sovieticus}

In the same way that Bultmann used the conceptual framework (Begrifflichkeit) of Heidegger as a means of illuminating the meaning of key biblical doctrines for his own time, Protestant theologians from the post-Soviet East can employ an existentialist hermeneutic towards the elucidation and critique of contemporary post-Soviet society. This article has highlighted two salient features of post-Soviet society: unfreedom and dehumanisation. These fundamental problems are, at root, spiritual in nature. The real difficulty with the reform of moribund structures of post-Soviet society lies not in any particular economic problem, but in the invisible structures of consciousness that form people's perception of public life and their social responsibilities. This means that the fundamental problem confronting post-Soviet society cannot be addressed adequately by political activism, but requires a theological analysis and interpretation. One of the greatest services that contemporary Protestant theology can render to post-Soviet society is to expedite the demise of homo sovieticus and thereby to prepare the way for a new anthropological prototype that cherishes dignity and freedom, rather than servility and conformity.

Homo sovieticus corresponds in some respects with the notion of "das Man", formulated by Martin Heidegger as a means of critiquing the banal conventionality of social existence. ${ }^{61}$ Heidegger employed the term, das Man, to refer to an impersonalised mode of human existence that disdains higher transcendent realities and spiritual values. For das Man, life is devoid of ultimate meaning or value. The unique individuality of human beings is submerged under a collective, dehumanising ideology that demands conformity

\footnotetext{
${ }^{59}$ Oleg Turlak, cited in Cherenkov, 'Protestantism and Protest', 337.

${ }^{60}$ For instance, Cherenkov, in his book on the "culture of the influential minority", refers to his experience in negative terms of being "carried away" by existentialist philosophy. М. Н. Черенков, Культура влиятельного меньшинства (Симферополь: Ассоциация Духовное возрождение, 2010), 200.

${ }^{61}$ Heidegger, Sein und Zeit (Tübingen: Neomarius Verlag, 1949), 126-30.
} 
and rebukes anyone who attempts to rise above the mediocrity of the crowd. ${ }^{62}$ The dominant impulse of das Man is the spirit of averageness. ${ }^{63} \mathrm{He}$ is fearful of originality and creative genius. Das Man hopes for little more than a comfortable habitat and the supply of his daily needs to gratify the vulgar desires of his mundane mind. Within this mediocre sphere of existence, das Man lacks a sense of transcendent purpose and direction and simply drifts aimlessly through life. Swept along passively with the ebb and flow of popular sentiment, das Man "accepts the stock of commonplaces, prejudices, fag-ends of ideas or simply empty words which chance has piled up within his mind." ${ }^{64}$ Under such conditions, the life of das Man "loses all authenticity, and is transformed into pure representation or fiction of another life." ${ }_{65}$ His free time, like the "weak and vicious" masses of Dostoevsky's Parable, is filled with trivial occupations and given over to "entertainment and amusement, to bright-eyed cheerfulness and dainty little children's songs ... and guiltless dances." "66 Das Man, in common with homo sovieticus, does not want democracy and liberty, because these would encumber him with the fearful burden of responsibility and free choice. Although the main target of Heidegger's social critique was the Western consumer society of mass production, the critique could be applied with equal potency to the system of Soviet communism.

Under the ideological direction of the all-powerful Communist Party, the Soviet system harnessed the power of propaganda and patterns of socialisation towards the mass production of homo sovieticus with the same ruthless dehumanising efficiency as its factories produced tractors and turbines. What post-Soviet society most needed following the ignominious demise of the USSR was a Nietzschean-style "transvaluation of values" 67 that would have not merely replaced a corrupt political system, but begun a process of social transformation that would have led eventually to the full repudiation of the USSR and its discredited dehumanising ideology ${ }^{68}$ By reinstating the fundamental values of freedom and dignity, Protestant theology can contribute towards the liberation of post-Soviet society from the crises of unfreedom and dehumanisation. By infusing these concepts with a positive Christian content, Protestant theologians can raise the public consciousness above the mediocre level of das Man by witnessing to a higher mode of existence.

Such an existence must be directed towards higher, transcendent goals and self-directed purposes. One of the basic convictions of existentialism is the connection between meaning and purpose. "Goal-setting" is the key to finding meaning in one's life. ${ }^{69}$ A meaningful

\footnotetext{
${ }^{62}$ Heidegger, Sein und Zeit, 129.

${ }^{63}$ Heidegger's critique of das Man draws heavily upon Nietzsche's critique of liberal democracy. Nietzsche castigated the "cursed instinct of mediocrity." See Nietzsche, Götzen-Dämmerung, in Giorgio Colli and Mazzino Montinari (eds.), Nietzsche: Kritische Gesamtausgabe, Volume 6 (München: DVT, 2008), 104.

${ }^{64}$ This corresponds to the notion of "the mass man", as depicted by the Spanish existentialist philosopher, José Ortega y Gasset. See Gasset, The Revolt of the Masses (London: George Allen and Unwin, 1961), 38, 53, 102.

${ }^{65}$ Gasset, Revolt of the Masses, 75.

${ }^{66}$ Достоевский, Братья Карамазовы, 239.

${ }^{67}$ Nietzsche, Der Wille zur Macht: Versuch einer Umwertung aller Werte (Leipzig: Kröner, 1930).

${ }^{68}$ Joshua T. Searle, 'No Revolution without Reformation: A Hegelian Reading of Maidan as a Civil and Religious Reformation', in van der Laarse et al (eds.), Ukraine: Religion, State, Society and Identity in Transition (Wolf: Oisterwijk, 2015), 299-318.

${ }^{69}$ Clifford Williams, Religion and the Meaning of Life: An Existential Approach (Cambridge: Cambridge University Press, 2020), 58-66.
} 
life is a purposeful life. Human life, in order to be deep and meaningful, must be dedicated to a noble enterprise that transcends the trivial cares of everyday life. As Gasset affirms, "Really to live is to be directed towards something, to progress towards a goal." 70 This can be achieved by articulating a new system of goals and values that are derived neither from Soviet communism nor Western capitalism, but from the life-giving teachings of the gospel. Theology aspires towards transcendence. Its criteria of truth are rooted within the eternal, incarnate Logos, rather than in the cultural pathos of the capitalist, neo-imperialist or post-Soviet Zeitgeist. Theology, which has criteria that lie outside the immanent points of reference within the cultural flux, can help to infuse the wider society with transcendent goals and values that direct people towards the light and life of the gospel. For the reasons I have set out in this article, I am of the firm conviction that these life-giving teachings can be made accessible to people in the former Soviet Union if they are expressed in the existentialist language of freedom and dignity.

By reinstatating the infinite dignity of the human person as being of incomparable value, existentialism confronts the dehumanising currents of thought that persist not only within post-Soviet society, but also within the post-Soviet church, which has inherited many of the pathologies, such as corruption and the lust for power, that afflicted the defunct Soviet system. Greater awareness of the treasures of the existentialist tradition (in both its Eastern and Western manifestations) could help post-Soviet Protestant theologians to address urgent public issues with greater nuance and depth. One of the problems with post-Soviet Protestant theology is the lack of a tradition of applying biblical and theological categories towards the elucidation and critique of social and political issues. Evangelical responses to salient issues that emerge from the public sphere are often devoid of a theological basis and sometimes even directly contradict fundamental biblical-theological principles. ${ }^{71}$ Therefore, instead of interpreting the cultural and ideological trends in post-Soviet society with depth and rigour, post-Soviet evangelicals have tended simply to assert their beliefs in a dogmatic way against anything that seems to challenge their evangelical worldview.

\section{Conclusion}

Today post-Soviet society has to contend against a noxious combination of postmodern nihilism and post-Soviet authoritarianism. The emerging postmodern condition, as it has taken root in the soil of post-Soviet culture, has created a pervasive sense of cynicism. Many nations of the former USSR, most notably Russia, are entering into a new era of authoritarianism. The decline into oppressive autocratic forms of government in the political sphere is facilitated by a wider tendency in culture to repudiate the value or even the existence of dignity and freedom. In the new "post-truth" world of post-Soviet culture in which "nothing is true and everything is possible", ${ }^{72}$ we are witnessing the advent of a new faithless age in which people have lost the ability to distinguish between love and hate, freedom and slavery, and truth and falsehood. The challenges for Christian witness

\footnotetext{
${ }^{70}$ Gassset, Revolt of the Masses, 108.

${ }^{71}$ For examples of such ineffective witness, see Searle and Charenkov, Future and a Hope, 66-68.

${ }^{72}$ Peter Pomerantsev, Nothing Is True and Everything Is Possible: The Surreal Heart of the New Russia (London: Faber and Faber, 2015).
} 
within such an adverse environment are formidable. Yet against such a dark cultural and political backdrop, the gospel virtues of freedom, truth and compassion will shine even brighter. Berdyaev, writing at a time in which the world was plunged into the darkness of the First World War, Berdyaev wrote that "the night is no less splendid than the day, no less divine. The night is illuminated by the stars and brings to light that which is invisible during the day." 73

In order to prevent the post-Soviet transition from becoming a mere chaotic interregnum between two dark periods of authoritarianism (Soviet Communism and Russian neo-imperialism), theologians need to take responsibility for the public good. ${ }^{74}$ Theologians cannot help but be active participants in the spiritual and social processes that are taking place in their cultural contexts. As I have maintained throughout this article, one of the ways in which post-Soviet Protestant theologians can participate creatively in directing these processes towards the streams of social renewal and spiritual regeneration is by drawing on the riches of the existentialist tradition, particularly concerning the theological elucidation of the key concepts of dignity and freedom.

Moreover, in their endeavours to understand the concept of freedom and its application to post-Soviet society, Protestant theologians can find inspiration in the prolific body of literature that has been produced by Eastern Orthodox theologians over several centuries. Within Eastern Orthodox theology there has been a persistent focus on freedom, which has been recognised not only by relatively marginal figures, such as Berdyaev, but also by the mainstream tradition, as one of the key concepts for understanding the nature and destiny of human life. Orthodox theologians today recognise that ever since Gregory of Nyssa, the Eastern/Byzantine tradition has regarded freedom as the "main component of the understanding of the divine image in humanity." 75 A fuller treatment of this tradition would exceed the scope of this article, but it is important to recognise that Eastern Orthodoxy opens up many promising lines of enquiry that could help post-Soviet Protestants today to understand the theological meaning, as well as the socio-political significance, of freedom for the contemporary world. ${ }^{76}$

Finally, some readers may object that the case I have made for the application of existentialism towards the renewal of the public witness of post-Soviet theology has been too uncritical or unnuanced. For readers who express this concern, it is important to remember that, as Macquarries remarked, 'both theology and philosophy move forward by violent swings of the pendulum, and that new or neglected truths can get a hearing only if they are put forward in exaggerated form. ${ }^{77}$ Therefore, even if one senses that the arguments

\footnotetext{
${ }^{73}$ Бердяев, Смысл творчества, 545. This book (English translation: The Meaning of Creativity) was first published in 1916.

${ }^{74}$ Joshua T. Searle, 'Public Theology After Maidan: New Points of Departure for Public Theology in the PostSoviet Space, The International Journal of Public Theology 14 (2020), 255-275.

${ }^{75}$ Sergej A. Čursanov, 'Freiheit (orthodox)', in B. Stubenrauch and A. Lorgus (eds.), Handwörterbuch Theologische Anthropologie: Römisch-katholisch/Russisch-orthodox (Freiburg: Herder, 2013), 256.

${ }^{76}$ One potentially promising approach would be that of the Russian Orthodox theologian, George Florovsky, who developed an original doctrine of creation and redemption from the perspective of divine-human freedom. See George Florovsky, The Collected Works of Georges Florovsky: Volume 3, Creation and Redemption (Belmont, MA: Nordland, 1976). See, especially, 45-73.

${ }^{77}$ Macquarrie, Twentieth Century Religious Thought (New York: Harper \& Row, 1963), 338.
} 
in favour of existentialism, as advanced above, have been overstated, I hope that even the alleged exaggeration can be excused in the greater interest of contributing towards the urgent renewal of post-Soviet Protestant theology's public witness.

\section{REFERENCES}

Berdyaev, N. Self-Knowledge: An Essay in Autobiography, trans. by K. Lampert. London: G. Bles, 1950.

—. O Naznachenii Cheloveka [Destiny of Man]. Moskva: AST Khranitel', 2006.

. Istoki i Smysl Russkogo Kommunizma [Origins and Meaning of Russian Communism]. Moskva: Nauka, 1990.

—. Ėkzistentșial'naiā Dialektika Bozhestvennogo i Chelovecheskogo [Existential Dialectics of Divine and Human]. Moskva: Astrel', 2010.

- Smysl Tvorchestva: Opyt Opravdaniia Cheloveka [Sens of the Creativity: An Essay on Justification of Man]. Moskva: AST: Astrel', 2011.

_. General'naī̄ Liniiā Sovetskoŭ Filosofii i Voinstvuiūshchĭ Ateizm [Mainline Soviet Philosophy and the Militant Atheism]. Paris: YMCA, 1932.

_. "Mirosozertsanie Dostoevskogo". In Berdiāev. Smysl Tvorchestva ["Worldview of Dostoevsky". In Berdyaev. Sens of Creativity]. Moskva: AST Astrel', 2011.

Bloch, E. Das Prinzip Hoffnung: Gesamtausgabe. Frankfurt: Suhrkamp, 1959.

Bockmuehl, K. The Unreal God of Modern Theology: Bultmann, Barth, and the Theology of Atheism: A Call to Recovering the Truth of God's Reality. Colorado Springs, CO: Helmers \& Howard Publishers location, 1988.

Bultmann, R. Theology of the New Testament, trans. by K. Grobel. Waco, TX: Baylor University Press, 2007.

Cherenkov, N. M. "Protestantism and Protest: Socio-Theological Re-Identification of Ukraine and Ukrainian Protestantism in the Context of Maidan". In Rob van der Laarse, Mykhailo N. Cherenkov, Vitaliy V. Proshak and Tetiana Mykhalchuk (eds.), Religion, State, Society and Identity in Transition: Ukraine. Oisterwijk: Wolf Legal Publishers, 2015.

Cherenkov, M. N. Kul'tura Vliiâtel'nogo Men'shinstva [Culture of the Influential Minority]. Simferopol': Assotșiatșiaa Dukhovnoe Vozrozhdenie, 2010.

Cherenkov, M i Bachinin, V. Protestantskaia ètika i dukh ...ostmodernizma [Protestant Ethics and the Spirit of ...ostmodernism]. Kyiv: Izdatel'stvo Knigonosha, 2015.

Congdon, D. W. The Mission of Demythologizing Rudolf Bultmann's Dialectical Theology. Minneapolis, MN: Fortress, 2015.

Čursanov S. 'Freiheit (orthodox)'. In B. Stubenrauch and A. Lorgus (eds.), Handwörterbuch Theologische Anthropologie: Römisch-katholisch/Russisch-orthodox. Freiburg: Herder, 2013. 
Dadabaev, T. Identity and Memory in Post-Soviet Central Asia Uzbekistan's Soviet Past. London: Taylor and Francis, 2015.

Denysenko, A. Teolohiiā Vyzvolenniā: Idë̈, Krytyka, Perspektyvy [Theology of Liberation: Ideas, Critique, Perspectives]. Kyiv: Dukh i Litera, 2019.

Dialektischer und historischer Materialismus: Lehrbuch für das marxistisch-leninistische Grundlagenstudium. Berlin: Dietz, 1976.

Dymyd, M. Bohoslov'ia Svobody: Ukraïns'ka Versiia [Theology of Freedom: A Ukrainian Version]. L'viv: Vydavnytstvo Ukraïns'koho Katolyts'koho Universytetu, 2020.

Dostoevskiŭ, f. Brat'ia Karamazovy [The Karamazov Brothers]. Moskva: Bertel'smann Media Moskau, 2014.

Florovsky, G. The Collected Works of Georges Florovsky: Volume 3, Creation and Redemption. Belmont, MA: Nordland, 1976.

Freeland, C. Sale of the Century: Russia's Wild Ride from Communism to Capitalism. New York: Random House, 2000.

Fukyuama, F. The End of History and the Last Man. London: Penguin, 1992.

Gasset, J. The Revolt of the Masses. London: George Allen and Unwin, 1961.

Grenz, S. and Olson, R. 20 $0^{\text {th }}$ Century Theology: God and World in a Transitional Age. Downers Grove, IL: InterVarsity Press, 1992.

Heidegger, M. Sein und Zeit. Tübingen: Neomarius Verlag, 1949.

Kierkegaard, S. Kierkegaard's Writings, XVIII: Without Authority, ed. by Howard V. Hong and Edna H. Hong. Princeton, NJ: Princeton University Press, 2009.

-. "Truth/Authority". In Frederick Sontag (ed.), A Kierkegaard Handbook. Eugene, OR: Wipf and Stock, 2003.

Macquarrie, J. An Existentialist Theology: A Comparison of Heidegger and Bultmann. London: SCM, 1956.

—. Twentieth Century Religious Thought. New York: Harper \& Row, 1963.

Marx, K. Grundrisse der Kritik der politischen Ökonomie. Berlin: Dietz, 1974.

Nietzsche, F. Götzen-Dämmerung, in Giorgio Colli and Mazzino Montinari (eds.), Nietzsche: Kritische Gesamtausgabe, Volume 6. München: DVT, 2008.

- On the Genealogy of Morality, ed. By K. Ansell-Pearson. Cambridge: Cambridge University Press, 2006.

—. Der Wille zur Macht: Versuch einer Umwertung aller Werte. Leipzig: Kröner, 1930.

Parushev P. and Pilli T. "Protestantism in Eastern Europe to the Present Day". In Alister McGrath and D. C. Marks (eds.), The Blackwell Companion to Protestantism, 155-60. Oxford: Blackwell, 2004.

Pomerantsev, P. Nothing Is True and Everything Is Possible: The Surreal Heart of the New Russia. London: Faber and Faber, 2015. 
Sartre, L'Existentialisme est un Humanisme. Paris: Nagel, 1946.

Searle, J. T. 'Public Theology After Maidan: New Points of Departure for Public Theology in the Post-Soviet Space'. The International Journal of Public Theology 14 (2020): 255-75.

—. "The Reformation in Russia and Ukraine and its Relevance for Today". European Journal of Theology 26.1 (Spring, 2017): 55-64.

- 'No Revolution without Reformation: A Hegelian Reading of Maidan as a Civil and Religious Reformation', in van der Laarse et al (eds.), Ukraine: Religion, State, Society and Identity in Transition, 299-318. Wolf: Oisterwijk, 2015.

Searle J. T. and Cherenkov, M. N. Future and a Hope: Mission, Theological Education and the Transformation of Post-Soviet Society. Eugene, OR: Wipf and Stock, 2014.

Snyder, T. Road to Unfreedom: Russia, Europe, America. London: Bodley Head, 2018.

_. Bloodlands: Europe between Hitler and Stalin. London: Vintage, 2011.

Tillich, P. Systematic Theology: Volume 1. London: Nisbet, 1963.

Volkov, V. "The concept of kulturnost': Notes on the Stalinist civilizing process". In Sheila Fitzpatrick (ed.), Stalinism: New Directions, 210-230. London: Routledge, 2000.

White, M. D. "Dignity”. In The Oxford Handbook of Ethics and Economics. Oxford: Oxford University Press, 2019.

Williams, C. Religion and the Meaning of Life: An Existential Approach. Cambridge: Cambridge University Press, 2020.

Woodson, H. Existential Theology: An Introduction. Eugene, OR: Wipf and Stock, 2020.

Zinoviev, A. Homo Sovieticus, trans. by Charles Janson. New York: Atlantic, 1986.

Joshua Searle

Towards a Theology of Dignity and Freedom: Existentialism and the Prospects for Reform of Protestant Witness to Post-Soviet Society

Abstract. This article examines how existentialist approaches to theology can be applied towards the elucidation of the meaning of dignity and freedom in post-Soviet society. The first part identifies key relevant characteristics of existentialism. The next section explores the relevance of existentialism for the context of post-Soviet Eastern European society through a critical examination of the concepts of dignity and freedom from an existentialist perspective, drawing primarily on the insights of Nikolai Berdyaev. Finally, the article addresses the contribution that Protestant theology could make towards the critique and renewal of post-Soviet society through a creative application of key concepts and ideas associated with existentialism.

Key words: existentialism, post-Soviet context, public theology, protestantism, Nikolai Berdyaev. 


\section{Джошуа Серль}

К теологии достоинства и свободы: экзистенциализм и перспективы реформы протестантского свидетельства в постсоветском обществе

Аннотация: Эта статья исследует, как экзистенциальные подходы к богословию могут быть применены к разъяснению значения достоинства и свободы в постсоветском обществе. В первой части определены ключевые характеристики экзистенциализма. В следующем разделе изучается актуальность экзистенциализма в контексте постсоветского восточноевропейского общества посредством критического анализа концепций достоинства и свободы с точки зрения экзистенциализма, в основном опираясь на идеи Николая Бердяева. Наконец, статья рассматривает вклад, который протестантское богословие может внести в критику и обновление постсоветского общества через творческое применение ключевых концепций и идей, связанных с экзистенциализмом.

Ключевые слова: экзистенциализм, постсоветский контекст, публичная теология, протестантизм, Николай Бердяев.

Джошуа Серль

Колледж Сперджена, Лондон, Великобритания

Joshua Searle

Spurgeon's College, London, United Kingdom

ORCID: 0000-0001-8901-2136

Надійшла до редакціії / Received 10.07.2021

Прийнята до публікації / Accepted 17.09.2021 